\title{
A Nolan Committee for the German ethics infrastructure?
}

\author{
NATHALIE BEHNKE \\ Fern Universität Hagen, Germany
}

\begin{abstract}
An international trend towards establishing and conforming standards of ethical behaviour in the public sector has repeatedly been stated. Germany, however, remains surprisingly reluctant to adopt such recommendations. This article argues that the likelihood of German decision makers implementing new, and especially soft, ethics measures depends on the demand for such measures, on the one hand, and their supply, on the other. The analysis shows that contradictory forces have an impact on Germany. The demand for new ethics measures is relatively low as a high level of hard ethics measures incorporated in the longstanding formal legal system of rules and regulations make the implementation of new measures seem unnecessary. Also, the demand for soft ethics measures is less marked in Germany than in the United Kingdom. This comparatively weak pressure meets the natural inertia caused by cognitive and institutional path-dependency in institutional choices of political decision makers. On the other hand, external bodies (such as the Organisation for Economic Cooperation and Development - OECD) provide blueprints for soft ethics measures and encourage the implementation of uniform standards across countries. Which of these forces will prevail in the long run, however, cannot be deduced from the present situation.
\end{abstract}

\section{Introduction}

On 25 October 1994, the British Prime Minister John Major established the Committee on Standards in Public Life (soon called the 'Nolan Committee' after its first chairman, Lord Nolan, but currently called the 'Neill Committee'). Its task was:

To examine current concerns about standards of conduct of all holders of public office, including arrangements relating to financial and commercial activities, and make recommendations as to any changes in present arrangements which might be required to ensure the highest standards of propriety in public life (Hansard 25 October 1994, col. 758).

The establishment of the Nolan Committee came as a reaction to a major political scandal which became known as the 'Cash for Questions Affair' (Leigh \& Vulliamy 1996). In its annual reports, the Committee has proposed 
institutional and procedural measures aimed at enhancing ethical standards in the public service, many of which have since been implemented (Whetnall 1996: 2ff). Thus, during the past few years, Britain has become one of the leading Western countries with respect to its willingness to develop and implement reforms in this area (Heywood \& Wright 1997: 90; Clark 2000: 27).

Germany has also experienced major and minor scandals in its history, but probably the worst of them came in 1999. A system of so-called 'black accounts' and large-scale money laundering, meticulously well organised by the German conservative party (the CDU) during the chancellorship and party leadership of Helmut Kohl, was discovered and made public. The scandal aroused much public indignation and triggered a turnover among senior office holders in the CDU. But the political and institutional consequences that can be observed two years after the scandal emerged are very different from those found in the British case. 'Ethics', as it is used in the Anglo-Saxon debate, has not become a salient political issue for German politicians. Laws have been drawn up or revised, a parliamentary investigative committee established and several judicial investigations and criminal proceedings initiated (and mostly stopped), yet no ethics committee was established or code of conduct issued. The relevant political actors showed a clear inclination to treat the affair as a legal matter rather than a political question of ethical standards. This is not to say that the public, especially the media, adopted this standpoint as well. In newspaper commentaries and public debate, the moral aspect of the affair was stressed. The actions of politicians, however, clearly emphasised the legal aspects.

This finding, as far as political elites are concerned, supports a general impression of Germany's reluctance to adopt and put into effect ethics measures. There is clearly an international trend towards establishing and harmonising standards of ethical behaviour in the public sector (Philp 2000; OECD 2000), the main promoter of which is the OECD. The blueprints and yardsticks offered by the OECD are taken from the Anglo-Saxon example, namely that of the United States and Britain. The experience of the American Office of Government Ethics (OGE), but also of the Nolan Committee, contributed substantially to the ideas diffused by the OECD of what makes up an ethics infrastructure in a country (Gilman 2000: 137ff; OECD 1996: 43). The notion of 'ethics' introduced there, however, does not seem to fit the German self-conception marked predominantly by legal regulations. In a survey conducted by the OECD in 1999 among all member countries, the German country report (OECD 2000: 155-166) exclusively listed as recent measures a tightening of legal provisions. Generally, the report emphasised that there is no need to implement new ethics measures in Germany. 'Evalu- 
ation of cases of misconduct that have been identified, in particular in the context of disciplinary proceedings, has not furnished any indication of significant changes as regards the period under consideration (OECD 2000: 155). The question that emerges here is in what respect the Anglo-Saxon approach to implement ethics measures is superior to the German, and whether Germany should thus adopt the notion of 'ethics' as it is used in the AngloSaxon countries and promoted by the OECD. This normative question of whether Germany should adopt the Anglo-Saxon notion of ethics, however, is not the main concern of this article. Rather, it focuses on the empirical question of trying to identify variables that make it more or less likely that Germany will adopt it.

The argument focuses on top politicians and administrative personnel in the public sector - that is, on parliamentary representatives, ministers and higher civil servants in ministries and departmental agencies. The comparison with the United Kingdom serves as a point of reference. Among European countries, the United Kingdom has taken the lead in implementing measures aimed at improving ethical standards. Furthermore, in many relevant institutional respects the United Kingdom is very similar to Germany. Both countries still have a comparatively unpoliticised civil service and function according to the logic of a parliamentary system, which implies a close connection between parliamentary majority and government, as well as ministerial accountability. Also, both countries have experienced similar patterns of economic and political development in the public sector during recent years marked mainly by financial shortage, privatisation and large-scale introduction of New Public Management (NPM) measures, which are closely linked to ethics measures.

The general theoretical assumption that lies at the heart of the argument is that the likelihood of implementing new ethics measures depends on the demand for measures, on the one hand, and the supply or availability of them, on the other. This assumption echoes Coleman's (1990: 241) differentiation between demand and supply of norms. A demand for ethics measures can be identified when the ethical problems generated by a situation call for specific rules or norms not already in existence. A catalogue of elements developed by the OECD (OECD 1996: 25ff) as a guideline for managing public ethics and termed 'ethics infrastructure' covers the most relevant ethical problems a public sector typically faces and indicates the kind of measures that should exist (see the section on the conception of an ethics infrastructure below). Yet, even if the demand for an ethics measure determines the function of the measure, the concrete form a measure takes can vary widely. This variation in the form in which a problem is solved depends on the institutional tool-kit 
political decision makers have at their disposition, which can differ significantly between countries. This is what is meant by the notion of 'supply of ethics measures'.

In the first step (see the second section of this article), the demand for ethics measures is assessed by comparing existing German ethics measures with those in the United Kingdom according to an 'ethics infrastructure'. In an ethics infrastructure, 'hard' elements can be distinguished from 'soft' ones. The aim of hard measures (mostly in the form of laws) is to tighten legal enforcement, control and sanction of standards of behaviour. On the other hand, soft measures (e.g., codes of ethics, mechanisms of self-control or declarations of commitment to ethical standards) have a rather symbolic function and aim to raise consciousness, demonstrate commitment and promote trust. It is assumed that if a country's ethics infrastructure conforms to the OECD model, the need for new measures is not very pressing.

In the second step, the demand for ethics measures is assessed in greater detail, based on the assumption that even if a country has an elaborate ethics infrastructure with plenty of hard measures, there may yet be a need for soft measures. Thus, while the demand is ascertained for ethics measures in general in the second section of this article, the third section is devoted to the demand for soft measures in particular. Recent developments in the administrative as well as in the political sphere are analysed in both countries. These developments generated situations that called for soft ethics measures because they could not be solved satisfactorily with hard measures. However, the reactions of the political leaders in the United Kingdom and Germany were quite different. The differences lie in part in the particular conditions prevailing in these two countries, they seem also to indicate a generalisable explanation.

This explanation is developed in the fourth section of this article through the consideration of the supply side of ethics measures. Explanations for variations in institutional tool-kits can be derived from institutional theory. It will be argued that the salience of particular ethics measures as institutional solutions to problems depends basically on two variables emphasised by different strands of new institutionalism. On the one hand (in the sociological reading of new institutionalism), actors tend to choose solutions that fit their inherited cognitive patterns and the existing institutional structures. This is an argument for institutional conservatism. Above all, the Roman Law and 'Rechtsstaat' traditions as elements of the German administrative and political culture shape the cognitive patterns of political decision makers, thus enhancing the salience of legal solutions. By contrast, Anglo-Saxon countries are marked by their Case Law and Common Law traditions and tend to want less systematic solutions. The salience of institutional patterns, however, is not static. Rather (in the historical-political reading of new institutionalism), the existing tool-kit 
can be enlarged or altered and the salience of new measures be enhanced by promotional activities of interested actors, in particular by international organisations. Which of these contradictory pressures will prevail in the long run, and whether a central ethics coordination body such as the Nolan Committee will be established in Germany in the near future, cannot yet be definitely answered.

\section{A yardstick for the demand of ethics measures: The ethics infrastructure}

\section{The conception of an ethics infrastructure}

The 'ethics infrastructure' was introduced as a tool for describing parsimoniously the structure of institutions, procedures and traditions that aim to promote ethical behaviour among public officials in a country. At its heart, as conceived by the OECD, lies the conviction that ethical behaviour can best be achieved through a combination of external and internal motivations (OECD 2000: 25). External motivation comes through negative incentives (sanctions) and control that compel compliance with existing proscriptive and prescriptive rules. The OECD (2000:25) terms this approach 'compliance-based ethics management'. Yet the kind of ethical behaviour produced by this approach is not reliable. Written rules can never be specified so precisely as to make sure that the intent of the rule is always furthered by formal compliance. This insight is highlighted by Luhmann (1994: 100) who stressed the importance of a 'functional informality' in organisations. 'Functional informality' can be described as the result of members' purposeful neglect of formal rules for the sake of attaining an organisational goal. Even if a structure were designed that relied merely on enforcement mechanisms, those mechanisms, too, must ultimately be backed by an acceptance of their legitimacy (Philp 2000: 9). That is why even advocates of formal rationality sooner or later come to recognise the importance of notions such as 'trust', 'responsibility' and 'integrity'. Hart (1994) argues that these values can be attained through an 'internal point of view'. An internal point of view can be distinguished from an external one in that it goes beyond formal obedience to rules. Only people who have an internal point of view are able to make use of norms as guidelines for appropriate social behaviour. This kind of internal motivation and integrity cannot be furthered by rules, control and sanctions, but must be evoked by persuasion, education and identification. The OECD termed this approach 'integrity-based ethics management' (OECD 2000: 25). Integrity is not intended to replace, but rather to complement, compliance. 
The elements of an ethics infrastructure are thus supposed to contain both 'hard' elements that stress external motivation through control and sanction, and 'soft' elements that promote internal motivation through guidance, information and identification (see Clark 2000: 29, who argues that 'soft law' regulation has increasingly been employed in the United Kingdom during the last six or seven years, focusing on codes of conduct and charters). Based on this idea, PUMA (the Public Management unit of the OECD) conducted a survey among member countries in order to find out what kind of ethics measures they had implemented (OECD 1996). As a result, eight elements likely to promote ethical behaviour among public officials have been developed and tested empirically (see Figure 1). Among these elements (subsequently referred to as 'E1' to 'E8'), the legal framework and the accountability mechanisms as well as a supportive public service environment are clearly 'hard' elements, whereas an ethics coordination body or the professional socialisation mechanisms are primarily 'soft' elements. As to political commitment and codes of conduct, it depends on the way in which commitment is expressed and on the content of the codes whether they are to be counted as soft or hard measures. The last element, the active civil society, is nothing that can really be promoted or enhanced by ethics measures. It emerges as the result of constitutionally guaranteed liberties and privileges, and a certain political culture.

1. Political commitment (E1)

Politicians should say ethics are important, set an example and support good conduct with adequate resources.

2. Workable codes of conduct (E2) Statement of values, roles, responsibilities, obligations, restrictions.

3. Professional socialisation mechanisms (E3) Education and training.

4. Ethics coordination body (E4)

5. Supportive public service conditions (E5) Fair and equitable treatment, appropriate pay and security.

6. Effective legal framework (E6) Laws and regulations which set standards of behaviour and enforce them.

7. Efficient accountability mechanisms (E7) Administrative procedures, audits, agency performance evaluations, consultation and oversight mechanisms.

8. Active civil society (E8) (Including a probing media) to act as watchdog over government activities.

Figure 1. Elements of an ethics infrastructure. Source: OECD 1996: 4 
On the other hand, an active civil society can put pressure on political decision makers, thus enhancing the subjectively perceived need to implement new ethics measures.

\section{The German and British ethics infrastructures}

Existing rules, laws, institutions and processes regulating the conduct of public servants and politicians constitute a complex framework for the behaviour of individuals, groups and organisations. Categorising this framework according to the elements of an ethics infrastructure is particularly fruitful in showing that, while the kind of situation a measure refers to may be very similar in different countries, the precise measure itself can be very different. Furthermore, it gives a complete picture of the status quo of ethics measures in the two countries, from which the demand for new ethics measures can be deduced.

\section{Commitment to ethics}

Commitment to ethical standards is expected from all public office holders, be they representatives, ministers or public servants. Any person entering the public service in Germany (ministers, civil servants and even public employees) must declare publicly or swear in an oath of office that he or she will behave according to the spirit and letter of the constitution. The declaration of loyalty to the constitution means primarily loyalty to the fundamental values and human rights laid down in Articles 1 to 19 of the German Basic Law, the most important of which is respect for human dignity (Article 1). ${ }^{1}$

British civil servants are nominally servants of the Crown, and the most fundamental values on which its public service ethos is built are loyalty and impartiality. In practice, loyalty to the Crown means loyalty to the Government of the day and thus to ministers. This relationship between ministers and civil servants, in particular the notion of 'political neutrality', has evolved over a long time and is not formalised in any written code or constitution (Richards \& Smith 2000: 48).

With regard to parliamentarians, commitment to ethical standards in Germany as well as in the United Kingdom is related to the notion of 'trust' in the Lockean and Burkean sense. This notion contains the tension between the representatives' accountability to the voters, on the one hand, and the essential freedom to decide according to their own conscience, on the other. In Germany, the free mandate is expressed in Article 38 of the Basic Law, and reliance on the representative's own conscience is emphasised by the standing orders of parliament: 'Every member of parliament follows his conviction and conscience in speeches, actions, votes and elections.' When elected to the House, British representatives have to swear an oath of allegiance 'to be faith- 
ful and bear true allegiance to Her Majesty the Queen, her heirs and successors, according to law'. Beyond this, parliamentary regulation is a matter of parliamentary privilege. Thus, in both countries, representatives' commitment to ethical standards is essentially a matter of self-control, albeit obviously within the limits of loyalty to the constitution.

\section{Codes of conduct}

In Germany, neither bureaucrats nor parliamentarians have their own written codes of conduct. Rules of behaviour, however, are contained in the constitution and in laws relating to the different positional groups, such as the Federal Civil Service Law or the Federal Ministers Law. Regulation for civil servants is highly fragmented in German law. The Basic Law requires the legislator to regulate the working conditions and status of civil servants. This task has been gradually fulfilled by issuing framework legislation in 1957 (Beamtenrechtsrahmengesetz) and, subsequently, a federal civil service statute and a civil service statute issued by each of the Länder. These 18 separate statutes are again supplemented by administrative orders of the Länder ministries. As the core of the regulations is quite comparable, however, reference in this article is made only to the federal civil service statute.

One major source of rules of behaviour for German public servants is the so-called 'traditional principles of the civil service' in Article 33, Clause 5 of the Basic Law. These traditional principles can be interpreted as an element of Common Law in the mainly codified German judicial system. Although they are not explicitly stated (except in legal commentaries on the Basic Law) and thus their content can in theory be changed, the general obligation to respect them is constitutionally protected. They include special duties as well as privileges, and express the particular character of public service as a relationship of mutual trust and loyalty. Accordingly, the duties stated in the traditional principles can serve as a guide or reference for public servants in deciding whether a political action is probate or not (for a list and interpretation of the traditional principles of the public service, see Lübbe-Wolff 1998: 714ff - also Haffke 1995:11; Wagner 1988: 102ff). More detailed rules of behaviour are found in the civil service statutes, such as loyalty, appropriate behaviour, impartiality, the duty to promote the common good, a restriction on publicly expressed private opinions, a ban on strikes or even the duty to care for one's own health and to extend one's knowledge (see Civil Service Framework Code (Beamtenrechtsrahmengesetz), sections 35 and 36; Federal Civil Service Code (Bundesbeamtengesetz), sections 52-76; comparable paragraphs are contained in the Länder Civil Service Codes (Länderbeamtengesetze)).

Behaviour in the British civil service is mainly a matter of tradition, as stated in a public service report of 1928 (the Estacode Report): 
It has never been thought necessary to lay down a precise code of conduct because civil servants jealously maintain their professional standards. In practice, the distinctive character of the British Civil Service depends largely on the existence and maintenance of a general code of conduct which, although to some extent intangible and unwritten, is of very real importance (quoted after a report by the Sub-Committee of the First Division Association 1972: 168ff).

However, even in 1972, the impact of such an unwritten code was seriously doubted by the authors of the Sub-Committee report. In 1990, the 'Civil Service Pay and Conditions Code was completely revised and updated (Chapman 1993: 163). It contains many relevant regulations of behaviour. Since 1997, the 'Seven Principles of Public Life' issued by the Nolan Committee are a further code of conduct applicable to all holders of public office.

Rules of behaviour for government ministers are found in Germany in the 'Joint Rules of Procedure of the Federal Ministries' (Gemeinsame Geschäftsordnung der Bundesministerien), which are paralleled by the British 'Questions of Procedure for Ministers' (Whetnall 1996: 6). The problem with these rules of behaviour is that they are only proscriptive. They forbid behaviour in great detail, but they do not explicitly set out forms of expected behaviour. This causes ambiguity and a high level of discretion in many situations (for a discussion of the related distinction between behavioural norms and norms of sanction, see Haffke 1995: 26ff).

The behaviour of parliamentarians is least formally regulated. This is in part due to the special position parliamentarians occupy. In contrast to public servants, they are not expected to act in an impartial way but to take positions and represent interests. This applies especially to those representatives elected directly for a constituency. In Germany, only one-half of the representatives in the Bundestag are elected directly for a constituency, whereas the other half are elected by proportional vote according to party lists. These representatives have the right and the duty to act responsively to their citizens and to defend their interests (Thompson 1993: 372ff). Thus the representatives' law in Germany (Abgeordnetengesetz) does not state any all-embracing values, presumably in order to avoid the political misuse of allegations of parliamentary misbehaviour (Roll 1989: 611). The appendix to the parliamentary standing orders, however, contains a list of rules of behaviour, which regulate primarily financial conflicts of interest. In the United Kingdom, most rules of behaviour can in theory be found in 'Erskine May', a comprehensive collection of rules and laws concerning parliamentary practice named after its original author, Thomas Erskine May. This source is, however, much too extensive to be used in practice as a guideline for standards of behaviour. Since the first Nolan 
Report was issued, the 'Seven Principles' serve as addition guidance for Members of Parliament (Oliver 1995: 45).

\section{Professional socialisation mechanisms}

Socialisation is the basis of soft regulation. People gradually learn the standards, values and rules of their profession and position. Control is internalised in the individuals, as they come to identify with their roles and the connected values. Traditionally, both countries have a closed civil service system. It ideally recruits young entrants around the age of 25 and trains them on the job, as they rise up the career ladder. Promotion is based on merit (for a detailed description of the function and position of the British civil service, see Fry 1985; of recruitment and training, especially the Civil Service Commission, see Chapman 2000; of recruitment, socialisation and political attitudes of the German civil service, see Derlien 1994). This process offers a useful mechanism for securing the internalisation of high standards of behaviour in the public service. The system of prevalent socialisation within the organisation, however, is breaking up, and the patterns of socialisation are changing (a development which will be returned to in the next section).

Politicians acquire their fundamental values and cognitive patterns during the long process of rising through their party ranks to political office (Patzelt 1999: 257). In both countries, elected representatives are, as a rule, members of a party - only rarely do 'independent' candidates succeed in winning a constituency. Not only parliament, but even government depends on the parties' recruitment and socialisation function, as it is mainly staffed by members of the majority party in parliament. In this way a close cooperation between the legislature and the executive is guaranteed. It may be argued that the lack of legal remedies against misbehaviour of parliamentarians is in part compensated for by strong party discipline and the internalisation of values (Roll 1989: 615). However, this view is oversimplified because it neglects the possibility of 'pathological learning' (i.e., of internalisation of rules and routines that encourage actions against the common good for the sake of the party).

\section{Ethics coordination body}

In Germany, there is no such thing as a central ethics coordination body. In the United Kingdom, the Nolan Committee can be said to have this function as it deals with questions of ethical behaviour for all parts of government and issues recommendations that unify and standardise the existing body of rules and traditions of ethical behaviour. Before the Nolan Committee was established, this function was in part assumed by the Civil Service Commission with regard to public servants. For more than a century (1855 to 1991; see Chapman 2000: 97ff) all public servants were recruited centrally by the Civil Service 
Commission. In developing and applying uniform selection criteria, the Civil Service Commission proved important not only for reducing corruption (Chapman 2000: 104), but also for creating a homogenous public service with high ethical standards. In the British parliament, furthermore, the Committee on Standards and Privileges is something close to an ethics coordination body. It had been created after the first Nolan Report by joining the Committee on Privileges, formerly the central self-regulation body in parliament (Oliver 1997: 449), and the Committee on Members' Interests (where Members of Parliament had declared their financial interests). It oversees the work of the Parliamentary Commissioner for Standards, who now maintains the Register of Members' Interests.

\section{Supportive public service conditions}

According to the OECD (2000: 24), a 'supportive public service environment' includes 'job security, opportunities for promotion and career development, fair remuneration or social appreciation'. These conditions are generally regarded as a necessary foundation for the loyalty of public servants to their employer, and thus as a minimum remedy against corruption. In both the United Kingdom and Germany, the privileged status of the public service has a long tradition and is deeply rooted in their administrative cultures. Germany has a two-track system of public servants, and discriminates between civil servants (Beamte) and public employees (Angestellte). Beamte are the traditional group in the public service and secured most of their privileges as early as the nineteenth century (Wunder 1974: 471ff). For a long time, they were also the largest group, but between 1990 and 1998 they were overtaken by the Angestellte (Derlien \& Heinemann 1998: 44). The privileged status of Beamte is even constitutionally fixed in the traditional principles according to Article 33, Section 5 of the Basic Law. Since the beginning of this century, those rights and the social prestige have been extended to Angestellte as the second largest group in the public service. In the United Kingdom, a comparably privileged status and high social prestige evolved over a series of public service reforms since the beginning of the nineteenth century. The best graduates from Oxbridge used to choose the civil service as a career, to the same degree they chose a university or senior managerial career (Campbell \& Wilson 1995: 40). With respect to a supportive public service environment, there is no difference between the two countries.

\section{Effective legal framework}

As legal regulations are part of nearly every element of the ethics infrastructure, in this subsection the focus is limited to the Criminal Code in Germany and the respective Common Law rules in the United Kingdom. The core 
regulations are found in Paragraphs 331 to 334 of the German Criminal Code. They state that bribery and 'accepting advantage' are criminal offences. Similarly, offering or taking a bribe is an offence in Common Law in the United Kingdom (Oliver 1997: 541). These offences are generally interpreted broadly in order to protect public confidence in the impartiality and incorruptibility of official actions and in the objectivity of decisions taken by officeholders and judges (Rudolphi et al. n.d.; German Criminal Code, comment to Paragraph 331). Accordingly, not only the corrupt act itself, but even the appearance of being bribed or accepting an advantage is relevant for establishing whether an offence has been committed. This means that even in cases where officeholders have accepted bribes but the bribe did not influence their decision, they could be convicted because they had undermined the belief in the incorruptibility of their office and thus violated the spirit of the law. The dividing line between instances when a gift can be accepted as a gift and those when it is to be seen as corrupting the officeholder is set out in particular statutes and orders (for public servants, the gift rule is specified in Article 70 of the Federal Civil Servants Statute $(B B G)$, for ministers in Article 5 of the Federal Ministers Statute (Bundesministergesetz); see Haffke 1995: 17ff).

In both countries, the offence of bribery applies only to holders of public office, not to representatives as holders of public mandate. Elected representatives are excluded from the scope of the German Criminal Code to stress the efficiency of parliament. It can be argued by analogy to the immunity of representatives guaranteed in Article 46 of the Basic Law that parliamentarians should be able to work unaffected by possible political uses of legal measures (Ebermayer \& Jagusch 1988; German Criminal Code, comment to Paragraph 331). However, a regulation comparable to Paragraphs 331-334 of the Criminal Code can be found in Article 44 of the Representatives' Law (Abgeordnetengesetz) and the code of behaviour for parliamentarians. ${ }^{2}$ Furthermore, a new part of the law added in 1994 (Article 108e) makes buying and selling votes a criminal offence (Haffke 1995: 21). It is very difficult, however, to prove that offence, so that the actual relevance of this Article may be doubted. When, in the course of the 1999 party finance scandal, the election in Hessen was legally challenged, applying this Article against the conservative (CDU) party leader, Roland Koch, was considered, but then not realised. In the United Kingdom, the exclusion of Members of Parliament (MPs) from the criminal laws on bribery and corruption is due to the tradition of self-regulation of parliament (Oliver 1997: 541), which implies that upholding public standards is a matter of parliamentary privilege (Hunt 2000: 30). Similarly, parliament does not count as a 'public body' with regard to the Prevention of Corruption Acts (1889-1916) and thus prosecution is possible only to a very limited extent (Oliver 1997: 542). 
Efficient accountability mechanisms

Accountability in the administration is, in both countries, traditionally oriented along the lines of hierarchy, the allocation of tasks and responsibility. Generally, the head of an agency is accountable to an external body. According to the tradition of ministerial accountability, ministers are accountable to parliament for their personal actions in their function as minister as well as for actions taken by their ministries (see Badura 1980; Bogdanor 1997). Faced with substantial complaints in parliament, the appropriate reaction for a minister is resignation. Inside a ministry or agency, every public servant is accountable to his superior. Thus, many cases of misbehaviour or conflict of interest, as long as they do not involve criminal offences, are dealt with internally by disciplinary procedure. In actionable cases, however, the courts are the last instance to secure control and accountability of officials' behaviour.

The administration (and, in Germany, the political parties as well) must formally present accounts to the audit office. Introduced as early as 1714 (Derlien 1992: 84), the German Courts of Accounts serve a double purpose. As regards the administration, they secure control; as regards political actors, they secure transparency which extends even to responsibility for party finances. In the United Kingdom, the role of auditor is in part filled by the National Audit Office (originally created in 1855 as the 'Exchequer and Audit Department', becoming the 'NAO' in 1983) and its head, the Comptroller and AuditorGeneral. The NAO oversees the budgets and programmes of the many NonDepartmental Public Bodies (NDPBs) and agencies created in the course of the privatisation wave in the 1980s and 1990s (Hood et al. 1999: 7, 73). Inside parliament, the budgetary control and investigation in mismanagement is exercised by the Parliamentary Commissioner for Administration (Punnett 1994: 373).

Parliamentarians are primarily accountable to their voters. Yet the voters' means of control and sanction are limited, a fact which is common knowledge in political science at least since Jean Jacques Rousseau's verdict on British democracy that: 'The people of England regards itself as free; but it is grossly mistaken; it is free only during the election of members of parliament. As soon as they are elected, slavery overtakes it, and it is nothing.' (Rousseau 1988: Book III, Chap. 15). In the first place, their chances of punishing a politician by not re-electing him or her are restricted to election periods. Second, even when applying a calculus of retrospective voting (Downs 1957; Fiorina 1981), this has only ever been a post hoc sanction, and there is no chance of binding politicians prospectively to good behaviour. Here again, securing standards is de facto and de jure a matter of parliamentary self-control. ${ }^{3}$

For parliamentarians, potential conflicts of interest are to be avoided by declarations of financial interest. German representatives hand their declara- 
tions to the parliamentary president. Attachment 1 to the Rules of Procedure of the German Parliament (Geschäftsordnung des Bundestages) lists the cases when a representative must declare a potential conflict of interest. These include positions held before being elected to parliament or during membership in parliament, as well as other contracts and pay for outside employment. Generally, these provisions rely strongly on the representatives' honesty, as mechanisms of control and sanction are not clearly specified and are only applied very cautiously. More important than the individual members' declarations are the parties' financial accounts. According to the Basic Law (Article 21), the parties have to account for the origin and use of their financial means and property, which includes the declaration of donations. These provisions have been specified in the Party Law passed in 1967 and been revised several times since (Maurer 1999a: 338). In the United Kingdom, MPs have, since 1974, had to declare their financial interests in the Register of Members' Interests. However, the Committee on Members' Interests, which administered the register, was not really taken seriously, not least because registration was voluntary and the Committee had no effective means of control (Doig 1998: 38). Many members of the House regarded registering their interests as useless, 'partly because members of the closed circle of the House tended to know what interests other members represented, partly because a formal register reflected on the individual honour of MPs and partly because it would, in any case, be ineffective (Hansard 1975, cols. 742-743, quoted after Hunt 2000: 27). In 1997, after the first Nolan Report, the register of interests was taken over by the Parliamentary Commissioner of Standards (Oliver 1997: 543).

While, in the United Kingdom, the government is held accountable by parliament in an informal manner through its offering or withdrawing general support, the German parliament can use a formal instrument of parliamentary investigative committees according to Article 44 of the Basic Law. The scope of these committees is usually restricted to scrutinising actions of members of government or governing parties in cases of alleged misbehaviour or when a case is of clear public interest (Maurer 1999a: 453) - yet they have no powers of sanction. Although their responsibilities have been clarified recently by an Investigative Committee Act, their composition is a major problem. Members are recruited in proportion to the seats of the parliamentary parties. Due to the close connection between majority party and government in a parliamentary system, the investigative committee, which was intentionally introduced as a means for parliament as a whole to control the executive, is mostly used as a (rather weak) means for the opposition to control the parliamentary majority and the government.

This weakness of investigative committees is best illustrated by the investigative committee established in 1983 to investigate the Flick Affair. The 
disclosures made in the committee were primarily due to the members of the Green Party, which was represented in the Bundestag for the first time in 1980. Thus they were the only party not corrupted by Flick's manager, von Brauchitsch, who had invented the phrase 'cultivation of the political landscape' as a euphemism for his practice of bribing all parliamentary parties. This way he made sure that he could always find support for his priorities. Consequently, none of the established parties were interested in investigating von Brauchitsch's dealings thoroughly. Thus, the impact of the investigative committee depended crucially on the Green Party members of the committee and their willingness to find out the truth (Landfried 1994).

\begin{abstract}
Active civil society
The relevant rights and freedoms that are necessary conditions for the development of an active civil society are long established and guaranteed in both countries. In Germany, the freedom of expression, of association and assembly (Vereinigungs- und Versammlungsfreiheit) and of the press are part of the basic human and civil rights laid down in Articles 1 to 19 of the Basic Law. In the United Kingdom, the guarantees of life, liberty and property date back as far as the Magna Carta (1215). The right to petition, free elections and the freedom of expression are secured in the Bill of Rights (1689). The traditions of a free civil society have their origins in the United Kingdom and have been copied all over the world.
\end{abstract}

\title{
Predominance of hard measures in Germany
}

In reviewing the ethics infrastructures in the two countries, several preliminary results can be emphasised. First, with the exception of the second and explicit codes of ethics and the fourth element - an ethics coordination body - each element can be found in Germany. If the OECD ethics infrastructure is taken as a yardstick for the demand for new ethics measures, then this demand is obviously not very high in Germany. Second, those elements identified above as typically strong measures - a legal framework, accountability mechanisms and supportive public service conditions - are particularly well elaborated. When compared to the United Kingdom, the content of these elements is not very different, but regulations in Germany always refer to an article in the constitution or a particular law or code. In the United Kingdom, by contrast, due to the Common Law tradition, the regulations are rather informal, and their content is continuously evolving and adapting and open to new interpretation. Third, those elements without a clear classification as either soft or hard measures - political commitment and codes of conduct - are shaped as hard measures in Germany, as they are again part of 
690

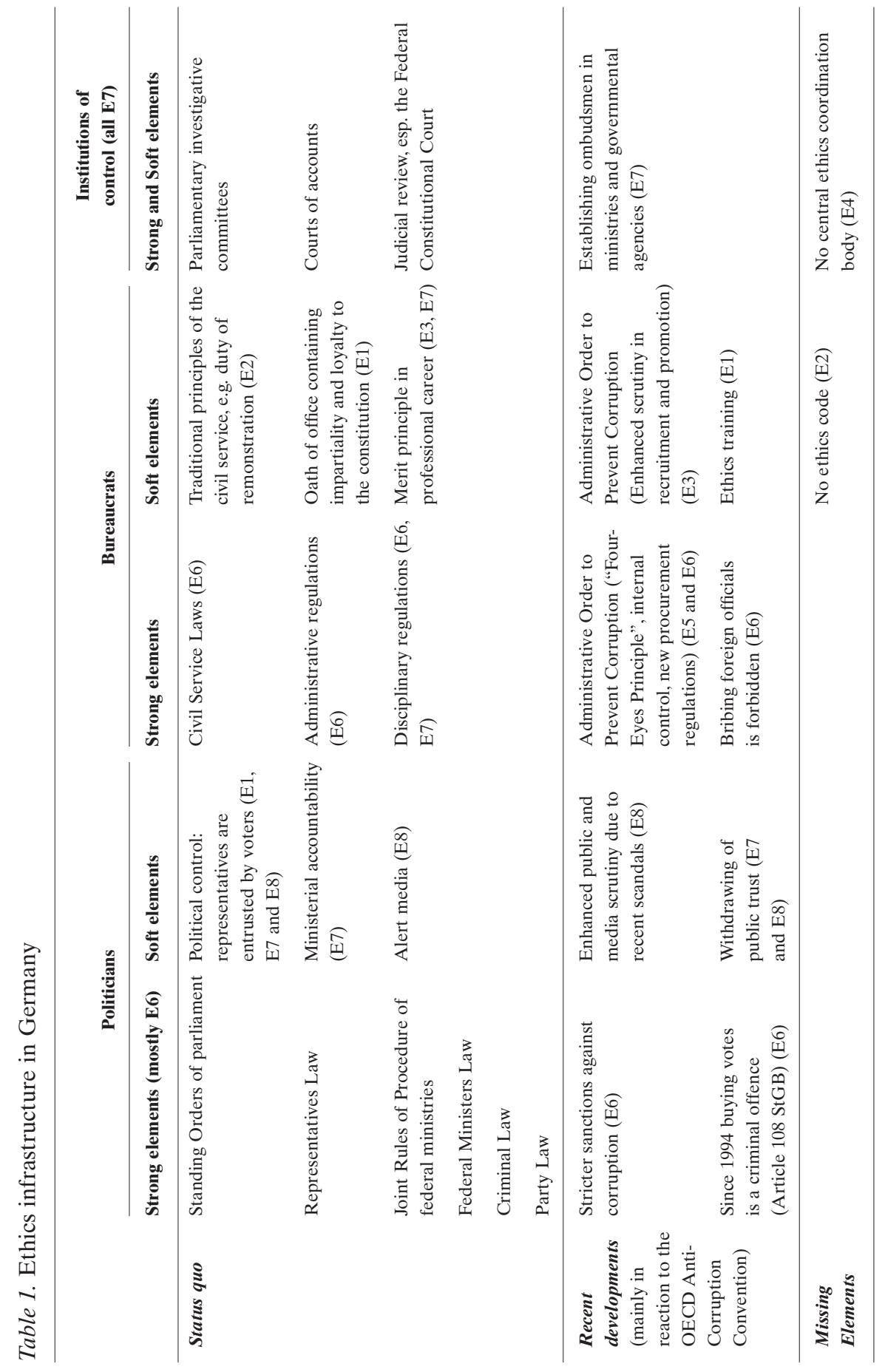


constitutional articles, laws and rules. In the United Kingdom, however, the informal aspects dominate. Internal socialisation, finally, is the only element classified as soft which shows - at least at first glance - not much difference between Germany and the United Kingdom. The more recent developments of this aspect will be investigated in depth below.

\section{The demand for soft ethics measures}

\section{General trends}

The analysis of the German ethics infrastructure proved that it contains most elements proposed by the OECD, but all in the form of hard ethics measures. Some problems and recent developments, however, cannot be dealt with exclusively with hard measures because they are too complex and ambiguous. The legal provisions, which are certainly important, need to be backed by such intangible values as 'trust', 'identity', 'integrity' and 'responsibility', which are promoted by soft measures.

One of these problems is linked to the idea of 'compliance-based management' (see above). Many situations leave space for interpretation of the existing rules and it is thus necessary for decision makers to have an 'internal point of view' (Hart 1994: 90) as regards the ethical values at stake. One major aspect of the 'New Public Management' (NPM) reforms of the last 10 or 15 years was the decentralisation of decision units and the concomitant increase in the discretionary power of public administrators to respond to more complex tasks of integrated planning or budgeting (Lawton \& Rose 1994: 134ff) in an internationalised environment (Hood et al. 1999: 75ff). This implied a shift in emphasis from external control and detailed regulation to self-control and performance measures. With enhanced discretion and performance management, it is even more important that the administrators take an 'internal point of view' and be conscious about situations that contain an ethical dilemma. This development underpins the importance of soft ethics measures such as training, information and advice.

Another problem is the declining impact of socialisation in the public service. Generally, identification with a public service role and adherence to the values connected to it are acquired in the process of socialisation. Professional socialisation mechanisms were believed to be so deeply rooted in the administrative cultures of the two countries that they represented an unproblematic aspect of the ethics infrastructure. In fact, a recent trend calls this opinion into question: the increasing number of outside entrants into the administrative as well as in the executive political arena. Career patterns have 
become ever more diversified, and the traditional lifelong learning, though still prevalent, is becoming increasingly replaced by a high degree of movement between the private and the public sector. In this case, again, training, information and advice become crucial in providing those outside entrants with detailed knowledge about formal and informal standards of behaviour.

These two problems refer primarily to the administrative sphere. A third problem, however, is linked to the need for politicians to maintain their legitimacy based on general public support. This is often regarded as the most important incentive for politicians to engage visibly in ethical actions (Hodess et al. 2001: 6; OECD 1996: 9). The pressure for visibility, however, makes it difficult to draw the line between symbolic and substantial politics. In fact, the public sector now faces many problems that threaten to undermine this general support (OECD 2000: 28ff). Financial pressures have tightened substantially and restrict the leeway in developing new programmes and increase the pressure for efficiency and for justifying how money is spent. The concomitant decline in public trust in the integrity and efficiency of decisions taken in parliament as well as in government, summarised suggestively in the German term 'Politikverdrossenheit' ('politics fatigue'), calls for new forms of securing responsiveness and accountability among parliamentarians. Here, soft ethics measures such as public announcements committing politicians to high ethical standards, enhanced transparency and procedures or institutions of self-control can enhance public trust and restore the basis of legitimate political action.

\section{Administrators: Socialisation and training}

In both countries the traditional roles of bureaucrats and politicians are changing. The younger generations occupying public positions today hold different values and, due to more flexible career patterns, privatisation and outsourcing, people are no longer socialised exclusively within the public service. This effect is reinforced by the increasing politicisation of public servants in their career patterns as well as in their perception of their role. It interacts with the NPM reforms in several ways.

In the United Kingdom, the problem of politicisation is linked to what Hood et al. (1999: 78ff) call 'agencification': the increasing number of agencies with independent powers of recruitment due to the semi-privatisation of formerly public tasks. The decentralised recruitment for managerial positions in NDPBs attracts 'outsiders' rather than traditional civil servants (Campbell \& Wilson 1995: 45ff). Thus the traditional career pathways are changed in favour of persons socialised outside the civil service. In response to this trend, the need to codify standards of behaviour has increased. 'Even though the drive 
to "write things down" seems to be part of a long-term trend shaped by factors other than the entry of "uncouth businessmen" alone, it can be seen as a regulatory response to increased lateral entry to senior public-service positions' (Hood et al. 1999: 78).

In Germany, the effects of NPM reforms and politicisation are less intertwined than in the United Kingdom. Germany did not witness a flourishing of NDPBs similar to that experienced by the United Kingdom in the 1990s, in part because many tasks (such as the delivery of a National Health Service) were never centralised. Rather, the devolution of responsibility takes place within the traditional hierarchy and enhances discretion of those lower in the hierarchy. Politicisation obviously plays a role in recruitment and promotion, but it plays a particularly important role in Germany in resignations due to the institution of the 'political civil servant' (Politischer Beamter). New governments tend to 'clean' the public service more thoroughly than they used to in former decades. This interrupts lifelong career patterns, tends to synchronise civil servants' terms of office with those of executive politicians and increases the proportion of outside entrants who were not socialised within the public service but in the private sector or politics. While traditionally civil servants in Germany remained in the public service for their whole career, during recent years the number of higher civil servants moving into political positions has increased. For example, Eckart Werthebach, a former permanent secretary (Staatssekretär) in the Ministry of the Interior, became Senator in Berlin, and Willi Hausmann, former Permanent Secretary in the Ministry of Finance, became Managing Director of the federal organisation of the conservative party (Maurer 1999b). This trend is mirrored in the ever more ample use of the institute of the 'political civil servant' after changes of government.

An increased fluidity in the character of the public service is an expression of what was observed by British scholars (see, e.g., Goldsmith \& Page 1997: 147) as well: a change in the role expectations politicians have towards their civil servants. They are more likely to prefer partisan behaviour to neutral competence. In this regard, public servants might themselves have an interest in codifying their standards of behaviour in order to protect themselves against undue expectations of partisan behaviour by politicians. Campbell and Wilson (1995: 61ff) observed this in particular for the Thatcher government. In their interpretation, the initiative of the First Division Association to draft a Code of Ethics was aimed at protecting civil servants from undue expectations on the part of politicians, rather than limiting the leeway of civil servants' actions.

Thus politicisation and NPM reforms enhance the demand for soft ethics measures in two respects. On the one hand, it becomes more important to set out clearly the values and norms of behaviour as the number of outside 
entrants to the public service increases and the impact of internal socialisation declines. On the other hand, civil servants themselves may wish to defend their traditional roles by clear statements of their duties and values. Both factors play a greater role in the United Kingdom than in Germany, where they can also be observed, but did not develop the same importance. In Germany, NPM reforms where introduced in a way that conformed to traditional hierarchical principles, the privatisation of public tasks took place to a much lesser degree and politicisation was always higher (Mayntz \& Derlien 1989). Thus the protection of neutrality might be expected to be a minor preoccupation for public servants.

\section{Politicians: Regaining public trust}

The third problem is the role of the public in exerting pressure on political decision makers by providing or withdrawing trust and legitimacy. Public trust is the principal basis of legitimate political action in modern democracies, and the actions of political leaders have to be strongly guided by their perception of whether or not the public approves of their decisions or requires demonstration of more commitment. Whereas trust is tacitly assumed to underpin everyday politics, the issue arises explicitly when a political scandal emerges and becomes a subject of public debate. Two such scandals - the 'Cash for questions affair' in 1994 when John Major was Prime Minister and the CDU party finance scandal in 1999 during the Chancellorship of Gerhard Schröder - were outlined in the introduction to this article, and the respective reactions the political leaders took when confronted with it show - in spite of many similarities - clearly distinguishable patterns.

\section{The cash for questions affair}

In late summer 1994, three British MPs (among them two Junior Ministers) were alleged to have accepted bribes from a lobbyist for tabling questions in parliament (Berrington 1995: 432; Oliver 1997: 540ff). The media played a crucial role in the allegations. The Sunday Times further reported that, in an experiment carried out by two journalists, three more MPs had accepted a faked bribery offer (Doig 1998: 42). Two journalists from The Guardian, David Leigh and Ed Vulliamy, conducted in-depth research on the background and circumstances of the scandal, which they published in a book (Leigh \& Vulliamy 1996). As an immediate political consequence, the case of the three hoodwinked MPs was handed to the House of Commons Committee of Privileges. The Committee suggested rather mild penalties (to reprimand two of the MPs and suspend them for 10 and 20 sitting days, respectively, with suspension of salary, and no action proposed against the third MP (Oliver 1995: 
42ff)). The Committee argued that the expected standards of behaviour were evidently not common knowledge to all MPs and thus 'misperceptions' were likely. The two Junior Ministers resigned the following autumn.

The concomitant decline in public trust and the reported confusion about expected standards (Oliver 1995: 44) put pressure on John Major, so he institutionalised 'ethics' as a topic of major concern for government and the public sector as a whole. On 25 October 1994, he issued an order to establish a 'Committee on Standards in Public Life' which took up work in January 1995. Since then, it has collected piles of oral and written evidence on ethics issues and has issued seven reports, each focused on a particular aspect of public ethics, as well as annual reports to document its current work. The first report, issued in May 1995 after having investigated hundreds of witnesses and experts, proposed measures to regain public trust in the work of the public sector, focusing on the House of Commons, central government and non-departmental public bodies (NDPBs), especially the National Health Service. The proposals took the form of four general and 55 special recommendations (Oliver 1995: 44ff).

The four general recommendations of the Committee (Committee on Standards in Public Life 1995: 3) were:

1. The principles underpinning standards in public life should be restated (see Figure 2). (The seven principles defined by the Committee are quoted in full because they proved deeply influential not only in all branches of public life in the United Kingdom, but even for the international ethics debate (OECD 2000: 35).)

2. All public bodies should draw up codes of conduct incorporating these principles.

3. Internal systems for maintaining standards should be supported by independent scrutiny.

4. More needs to be done to promote and reinforce standards of conduct in public bodies, in particular through guidance and training, including induction training.

The other 55 recommendations refer to the different bodies: legislative, executive and NDPBs. They seek to make mainly procedural or institutional changes, such as the institution of a Parliamentary Commissioner of Standards (Woodhouse 1998), or a more rigorous enforcement of the registration of financial interests. Furthermore, the Committee drafted a Code of Behaviour for Parliamentarians (Oliver 1995: 46) and recommended legislative amendments aimed at protecting whistle-blowers (Whetnall 1996: 7). Most of them have meanwhile been implemented. (A general review and evaluation of the impact of the work of the Nolan Committee is given in Doig (2001: 370ff).) 


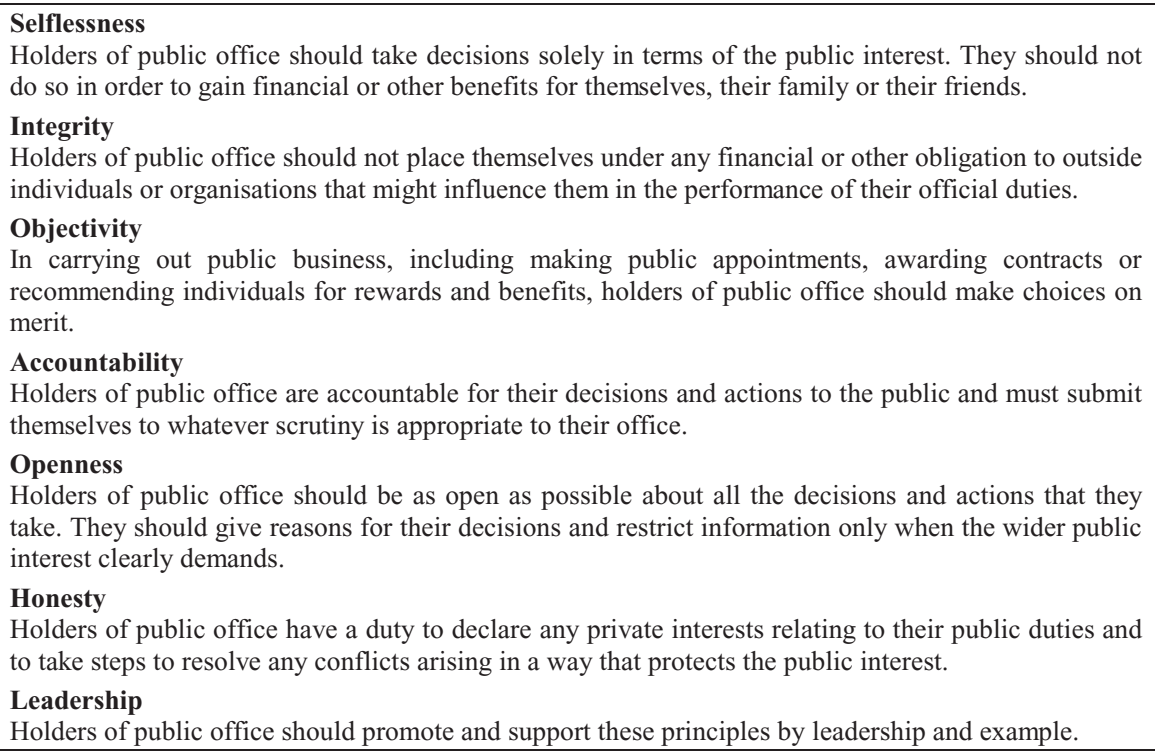

Holders of public office should be as open as possible about all the decisions and actions that they take. They should give reasons for their decisions and restrict information only when the wider public interest clearly demands.

Honesty

Holders of public office have a duty to declare any private interests relating to their public duties and to take steps to resolve any conflicts arising in a way that protects the public interest.

Leadership

Holders of public office should promote and support these principles by leadership and example.

Figure 2. The Seven Principles of Public Life.

Since 1997, the Committee on Standards of Official Conduct has become a standing committee. On 12 November 1997, Prime Minister Tony Blair announced an addition to its terms of reference in the House of Commons: 'To review issues in relation to the funding of political parties, and to make recommendations as to any changes in present arrangements' (Hansard 12 November 1997, col. 899).

\section{The CDU party finance scandal}

The German case differs from the British from the very beginning in that the courts and public prosecutors were more important than the media in discovering and unravelling the developing scandal. The role of the media, however, was to inform and alert the public. The public prosecutor and the tax office in Bavaria were investigating the case since 1995, but only after the Süddeutsche Zeitung published the first article on 9 November 1999 did it become a scandal. The continued reporting in all German newspapers gave the scandal high visibility and exerted pressure on the politicians, compelling them to admit details they tried to conceal. (Three journalists from the Süddeutsche Zeitung published a book in September 2000 that contained detailed research, as well as political commentaries on the scandal (Leyendecker et al. 2000).) Furthermore, personalities from the judiciary were given space by the leading newspapers to share their findings and impressions. For example, the evidence the former public prosecutor of Augsburg in Bavaria, Winfried Maier, gave to the 
Bavarian investigative committee was widely quoted and commented on in the Süddeutsche Zeitung (19-20 October 2001).

Although the pressure exerted by the public was notable, the political consequences of the scandal are limited to a very small circle of persons. Helmut Kohl lost his status and position within the CDU, and Wolfgang Schäuble resigned in February 2000 from his positions of party leader and leader of the parliamentary group and was replaced by Angela Merkel and Friedrich Merz, respectively. In Hessen, where most of the money laundering transactions took place, the Land Prime Minister (Ministerpräsident), Roland Koch, had to admit step-by-step his intimate knowledge of details of the financial transactions. Yet his position was challenged neither by the voters (in a subsequent communal election in Hessen, the CDU even gained more votes than before) nor by the Liberal Party as coalition partner of the CDU. In June 2001, legal proceedings were initiated against the former Minister of the Interior, Manfred Kanther. As a consequence, he resigned from the positions he had held in the Hessen CDU.

The formal-legal consequences, by contrast, are numerous. A number of courts at the federal and Land levels dealt with law-suits linked to the scandal. The administrative court in Berlin decided that the penalty imposed on the CDU according to the German Party Law by the President of Parliament (Bundestagspräsident), Wolfgang Thierse, according to which the CDU was compelled to repay the state funding it had received for the three years concerned, was not justified. An arbitration committee in Hessen investigated the validity of the Länder elections of February 1999, since the CDU campaign had been financed with 'black money', but in the end upheld their validity. Criminal proceedings were taken up against Helmut Kohl, but stopped for reasons of 'unclear facts' (Süddeutsche Zeitung, 03 March 2001). The court's official declaration stated that he was not guilty, yet he had to pay a forfeit of DM 300,000. Criminal proceedings for embezzlement were taken up against Manfred Kanther, the former Secretary of the Hessian CDU, in May 2001 and the case is still pending. Furthermore, a parliamentary investigative committee was established to uncover the background to the affair, but divergent opinions on the task and scope of the committee among its members delayed the inquiry. The official task of the investigative committee is focused on the 'black accounts'. For the committee members from the government parties, this implies inquiring into the personal involvement of Helmut Kohl, whereas the CDU members of the committee disagree. In reaction to the difficulties facing the investigative committee, the Bundestag finally fulfilled a task that had been given to it by the members of the Parliamentary Council when it drafted the German constitution back in 1949. A law was passed in June 2001 (Parliamentary Printing (BT-Drs.) 14/5790; Federal Law Gazette 
(Bundesgesetzblatt) 28: 1142-1148) defining the competencies of a parliamentary investigative committee (which had previously been indirectly derived from the Parliamentary Rules of Procedure and from the Code of Criminal Procedure (Maurer 1999a: 452)) that provides for the appointment of an independent prosecutor (Ermittlungsbeauftragter) similar to the position of the same name in the United States (for a discussion of the origins of this position, see Gilman 1996: 10). This was intended to strengthen the committees' investigative powers. Finally, the Federal President summoned a commission of experts to elaborate proposals for reforming existing legislation on party finance, the report of which was published in July 2001 (http://www.bundespraesident.de/Downloads.Bericht.pdf).

\section{The two scandals: Comparing the consequences}

The two scandals, which drove both the political systems into deep crisis, have many common features, yet are different in important respects. In the United Kingdom, the two Junior Ministers resigned; in Germany, Kohl, Schäuble and Kanther gave up their positions within the CDU. In both cases, disciplinary action was taken by parliament. The British parliament reprimanded two of the representatives who had accepted the fake bribe; the German President of Parliament imposed a fine on the CDU as a whole. The German Federal President, Johannes Rau, appointed a commission to elaborate proposals for a reform of party finance law. In the United Kingdom, this task was assumed by the Nolan Committee in 1997 in execution of the enlarged function given to it by Tony Blair. In both cases, legislation was revised, strengthened or updated, such as whistle-blower protection in the United Kingdom or the parliamentary investigative committee law in Germany.

Beyond these common reactions, the main difference can be observed in the predominance of legal consequences in Germany, whereas general standards of behaviour binding for all branches of government were set up in the United Kindom. If decline of public trust is a major incentive for politicians to implement soft ethics measures, then Major experienced probably a much steeper decline than Schröder. This expectation can, in fact, be validated by looking at the actual circumstances in each of the situations.

In 1994, Major was in a weak position in government and had to worry about his re-election in 1996. At that time, public support for the government was extremely low, in part due to the accumulation of several episodes related to ethical issues: a dubious government policy of supplying arms to the Middle East - the 'Matrix Churchill Affair' - in 1992, a series of sex scandals, cases where lavish gifts were accepted, several cases of alleged conflict of interest by former government officials who entered private-sector enterprises, and then the 'cash for questions affair'. In the course of these events, members of 
different parts of the public sector, government officials, public servants and parliamentarians undermined the public trust in the efficiency and integrity of government (Berrington 1995). Whether this public assessment was really justified at that time is unimportant. What counts is that it put enough pressure on John Major to fuel a commitment to ethics designed to strengthen his chances of re-election.

In Germany, too, the public was deeply indignant and disappointed by continual revelations of scandal, and sympathy for Helmut Kohl and the CDU declined even among their own partisans. According to monthly polls conducted by Politbarometer, the sympathy expressed for Helmut Kohl declined drastically in the months after the scandal was revealed. From April 2000 on, Kohl was no longer mentioned by respondents as being among the 10 most important politicians (see Politbarometer 10/99 to 4/00 at http://www.bdb.de/html/02_politik/sub_03_politbarometer/pol_03.asp). However, at that time, the CDU was in opposition, and not in government as was the Conservative Party under John Major in the United Kingdom. The head of government, Gerhard Schröder, by contrast, even could gain from the affair, as the trust and sympathy for his party and for the government coalition steadily increased after the beginning of the affair (see Infratest dimap, DeutschlandTREND, January 2001). The punishment meted out by public opinion was short-lived and directed exclusively against a small circle within the CDU. Thus, whereas Major had to make every effort to prove his trustworthiness, Schröder could react in a more relaxed manner, as the more deeply the CDU got involved in the scandal, the better the image of the government in the eyes of the public.

The fact that Schröder was not directly under pressure, however, explains neither the intensity and exclusivity of judicial involvement in the scandal, nor the complete insensitivity to the problem of unclear standards. Clearly, the involvement of the courts and public prosecutors can be explained by the legal dimension of the scandal wherein a series of laws had been definitely broken. However, issues such as the 'word of honour' presumably given by Kohl to his donors that he clearly placed above loyalty to the constitution, in spite of being hotly debated by the media, did not give rise to a political debate on unclear ethical standards.

\section{Supply of institutional conceptions}

\section{Salience and institutional path-dependency}

The finding of negligence of ethical standards and soft ethics measures fits with the findings of the preceding sections, where it has been shown that the ethics 
infrastructures, the development of recent trends in public administration and the reaction of politicians to a major scandal in Germany and the United Kingdom all offer evidence of distinctive national patterns. In Germany, a formal-legal approach in the Weberian sense is clearly predominant, stressing external control, the role of the judiciary and written rules at constitutional or parliamentary law level. In the United Kingdom, aspects of self-regulation and a high informality of rules and institutions prevail.

The high informality in the British public sector is particularly evident at the highest level, in the closely intertwined relationship between Whitehall and Westminster. This is what Heclo and Wildavsky (1974) termed the 'village', an atmosphere of high informality, personal knowledge and mutual social control that characterises the decision-making process in and around Whitehall:

For Heclo and Wildavsky what kept the high office-holders of government under control was not so much enacted rules and judicial or legislative oversight as a 'village culture' of common experience, shared values, and continuous mutual assessment of ability and trustworthiness over a career normally lasting over thirty years and mostly spent in a square mile of central London (Hood et al. 1999: 71).

Although during the past ten years things have changed in Whitehall and maybe the 'village' is no longer discernible as distinctively as Heclo and Wildavsky experienced it in 1974, the contrast with Germany still seems clear enough to stress this aspect of the British political culture.

Above all, the handling of the affair by John Major and Gerhard Schröder shows - despite the differences in circumstances - that actors tend to perpetuate in their decisions those cultural patterns into which they have been socialised. This is hardly surprising, as actors have to economise on their intellectual capacities and thus develop routine reactions (Simon 1955; Heiner 1990) that they apply to the situations with which they are confronted. Those routines provide the most salient patterns of reaction and, consequently, are regularly turned to. This assumption that 'institutions influence behaviour by providing the cognitive scripts, categories and models that are indispensable for action, not least because without them the word and the behaviour of others cannot be interpreted' (Hall \& Taylor 1996: 948) is one of the starting points in organisational institutional analysis (Cohen et al. 1972; DiMaggio \& Powell 1991). In the next section, this cognitive version of new institutionalism will be followed, looking at the institutional traditions that shaped the cognitive frame of German politicians.

At a general level, the notion of historical path-dependency of institutional solutions, as used by historical institutionalists, is related to the cognitive 
approach in that it 'rejects the traditional postulate that the same operative forces will generate the same results everywhere in favour of the view that the effect of such forces will be mediated by the contextual features of a given situation often inherited from the past' (Hall \& Taylor 1996: 941). Yet mostly the emphasis is not on cognitive patterns, but rather on structural power relations among conflicting groups (Thelen \& Steinmo 1992; Immergut 1997: 335). According to this view, the chances of an idea being implemented depend crucially on it being promoted by interested actors (Goldstein 1988; Weir 1989). In fact, the foci on cognitive patterns, on the one hand, and interested actors, on the other, are not mutually exclusive, but rather complement each other. Routine reaction patterns can be altered by interested actors if they provide a blueprint for alternative solutions and promote them to a high salience. This is what happens in ethics through international actors, such as the OECD, Transparency International, and others. Thus, in the last section of this article, an example will be given of the influence international actors exercise in Germany. This might indicate the direction in which the traditional way of institutional choice in Germany might change.

\section{Roman Law and the tradition of 'Rechtsstaat'}

The German ethics infrastructure is, as has repeatedly been shown in this article, deeply influenced by the hierarchical system of laws and rules derived from the Roman Law tradition in combination with the long-established notion of formal Rechtsstaat. This bureaucratic tradition is alien to the British system. While it is the oldest democracy, Britain does not have a written constitution. Yet in Germany, the Rechtsstaat tradition provides a background of scepticism, if not mere ignorance, of informality as an option for problemsolving routines in the modern public sector.

Roman Law, as re-introduced in Germany by Napoleon's Civil Code (1806-1810) (Voigt 1998: 139) and elaborated to perfection in the German Civil Code (1900), is fundamentally distinct from the Common Law and Case Law prevalent in the Anglo-Saxon countries. Roman Law is positively stated and hierarchically organised, and aims at regulating possible situations in an abstract and logical manner (David 1966: 353). It pervades and regulates all possible situations of human interaction, as can be seen in the distinction of civil law, public law, criminal law, trade law and many more. In Common Law, by contrast, rules and interpretations are developed by judges in concrete cases and according to precedent. Thus, the existing laws and statutes are not logically systematised but have evolved in response to new necessities and evidence (David 1966: 348). Many institutions and procedures are regulated informally or by codes without legal status. 
The typical German Rechtsstaat is historically influential in that bureaucracy acted in Germany as a promoter of democratisation and extension of civil rights from above. Individual rights were developed primarily as protective rights against intrusion of the state into the private sphere (Funk 1986: 37ff). Thus, an (essentially economic) sheltered sphere in combination with the fundamental principles of the Rechtsstaat (legal certainty (Rechtssicherheit), equality before the law (Rechtsgleichheit), and 'nulla poene sine lege' (Gesetzesvorbehalt)) was granted to the people before they gained political rights as citizens. Furthermore, German administration from the Prussian monarchy to the present has proven an impressive degree of continuity irrespective of the political systems of the day. From this historical background, where juridification has primarily meant protection from the state rather than limits to individual liberty, the German inclination to fix rights and duties in written documents becomes quite understandable.

\section{The role of external actors: Implementation of the OECD anti-corruption convention}

It is unclear whether soft ethics measures have not so far gained currency in Germany because people were only dimly aware that they existed or because they were deemed unnecessary. In both respects, international actors - above all the OECD, but also Transparency International, the European Union, the World Bank and the United Nations Organisation which increasingly launch ethics and anti-corruption initiatives - come to play an important role in changing the typical German reaction. On the one hand, they provide blueprints and yardsticks, thus enlarging the tool-kit for, and enhancing the salience of, possible institutional solutions. On the other hand, they exert pressure for cross-national convergence in standards and measures - a pressure German politicians hardly can avoid.

An example of this trend is the Anti-Corruption convention set out by the OECD in December 1997 and immediately signed by 33 states, including Germany. Signing the convention implied an obligation to ratify it domestically, an obligation Germany met in 1998 by passing the Act on Fighting International Corruption (Gesetz zur Bekämpfung internationaler Bestechung - IntBest $G$ of 10 September 1998, BGBl. part II: 2327ff). The Act inserts the criminal offence of bribing officials of foreign countries into the relevant sections of the Criminal Code.

This legal measure fits the traditional pattern of the German ethics infrastructure. More interesting, however, is an additional administrative order (Richtlinie der Bundesregierung) issued on 17 June 1998 by the federal Ministry of the Interior. The provisions made in this order include, among others: 
1. Identification of areas and processes particularly susceptible to corruption and securing of transparency, attention and control in these areas.

2. Rotation of personnel at fixed time intervals, as far as the specificity of the task permits

3. The establishment of 'ombudsmen', who have no disciplinary power, but shall permanently inform, communicate and give hints as to how to behave in critical situations.

4. Establishment of 'internal scrutiny' (Innenrevision), a kind of internalised controlling system to be activated by complaints and allegations of corruption.

5. Particular care and scrutiny at recruitment.

6. A draft code of behaviour for members of the public service.

7. Regular anti-corruption training for members of the public service.

This list of measures, which is only a selection of the provisions made in the administrative order (the others containing more formal provisions, such as regulations for procurement contracts or disciplinary investigations), indicates a clear shift in emphasis away from a legal monitoring of behaviour to achieving objectives through raising awareness, training and information. The rotation of personnel, which can be implemented only to a limited extent according to the official opinion of the government as expressed in a written answer to a parliamentary question (Bundestagsdrucksache 14/3933: 6), seeks to prevent undesirable forms of long-term bilateral relationships between public officials and enterprises. The establishment of ombudsmen serves the double purpose of signalling permanent control, but also of lowering the threshold for members of an organisation to report misbehaviour - whether their own or that of others. In particular, regular training, information and consciousness-raising are typical soft measures for maintaining standards of behaviour and preventing corruption. They have been debated intensely in Anglo-Saxon countries (see, e.g., Denhardt 1991; Kernaghan \& Dwivedi 1983), yet in Germany they have not yet been used as part of a strategy to promote ethical behaviour.

\section{Conclusion}

This analysis started with the observation that Germany is rather reluctant to adopt new ways of thinking about and implementing ethics measures in the public sector, although such new measures have been readily accepted in Anglo-Saxon countries and are being promoted by the OECD. According to the analytical framework presented here, the independent variables for the 
introduction of soft ethics measures are the demand for them on the one hand, and the supply of them, on the other. On the demand side, the general demand for ethics measures is furthermore distinguished from the particular demand for soft ethics measures. The supply side depends - in line with familiar arguments of new institutionalists - on salient cognitive schemes of political decision makers and the existing institutional structure, as well as on the influence of interested actors in proposing and promoting new institutional solutions.

The general demand for ethics measures was investigated using the categories of an ethics infrastructure with eight different elements. As a result, the status quo of ethics measures in Germany covers nearly all the elements proposed by the OECD, and thus does not suggest an overwhelming demand for new measures. As to the specific demand for soft ethics measures, the evidence is not so clear. Although the trends identified as enhancing the demand for soft ethics measures could be located in Germany as well, they are much less distinct than in the United Kingdom. So, although demand is also present in Germany, it is so low that it still remains below the threshold that triggers deliberate action. A threshold can be assumed because of the natural inertia towards change that lies in the path-dependency of institutional choices. The traditional institutions and routines in Germany show an inclination to formallegal regulation and do not encourage the implementation of soft ethics measures. Path-dependency, however, does not preclude learning, and the pressure to depart from the traditional path might increase so much that either public opinion in Germany is more insistent on soft ethics measures or that international actors increasingly influence national institutional choices. In which case, the establishment of a body similar to the Nolan Committee might not be so unlikely after all.

\section{Acknowledgements}

I was given the opportunity to clarify and defend the arguments exposed in this article in numerous discussions at the ECPR Joint Sessions 2001 and within my political science department. I particularly wish to thank Katrin Auel, Joachim Behnke, Maria Behrens, Arthur Benz, Rainer Eising and Martin List who read the article at different stages of development and made very helpful comments.

\section{Notes}

1. For public servants, another important value is non-discrimination and impartiality, as contained in Articles 3 and 33. Article 3 stipulates impartiality (no discrimination in the 
exercise of office) irrespective of sex, origin, race, language, religious belief or political convictions. Conversely, Article 33, Clauses 2 and 3, prescribes non-discrimination when entering a public office.

2. The Standing Orders of parliament (Geschäftsordnung des Bundestages) contain an attached code of behaviour. Article 1 regulates financial disclosure, Article 4 the acceptance of donations and Article 9 acceptance of gifts. Interestingly, a comparison of the respective codes of behaviour for members of the German and British parliaments shows that the British Code of Conduct for Members of Parliament from 1995 contains only general moral principles and appeals, whereas the Rules of Behaviour for Members of the German Bundestag state very precise legal provisions as regards declaration of financial interests, external income restrictions and procedures to investigate alleged misbehaviour. Thus, even where a rather informal way of regulating behaviour is chosen, the inclination towards legal formalisation is evident.

3. The parliamentary right to act autonomously in regulating its own affairs is laid down for Germany at a technical and general level in Article 40, Section 1, Clause 2 of the Basic Law (Maurer 1999a: 428ff). In the United Kingdom, this privilege is Common Law and dates back to a judgement in 1884 (Punnett 1994: 173).

\section{References}

Badura, P. (1980). Die parlamentarische Verantwortlichkeit der Minister. Zeitschrift für Parlamentsfragen 11: 573-582.

Berrington, H. (1995). Political ethics: The Nolan Report. Government \& Opposition 30: 431-451.

Bogdanor, V. (1997). Ministerial accountability. Parliamentary Affairs 50: 71-83.

Campbell, C. \& Wilson, G.K. (1995). The end of Whitehall. Oxford: Blackwell.

Chapman, R.A. (1993). Ethics in public service. in R.A. Chapman (ed.), Ethics in public service. Edinburgh: Edinburgh University Press, pp. 155-171.

Chapman, R.A. (2000). Setting standards in a new organization: The case of the British Civil Service Commission. in R.A. Chapman (ed.), Ethics in public service for the new millennium. Aldershot: Ashgate, pp. 93-110.

Clark, D. (2000). Public service reform: A comparative West European perspective. West European Politics 23: 25-44.

Cohen, M., March, J. \& Olson, J.P. (1972). A garbage can model of organizational choice. Administrative Science Quarterly 17: 1-25.

Coleman, J.S. (1990). Foundations of social theory. Cambridge, MA: Belknap.

Committee on Standards in Public Life (1995). Standards in public life (first report). London: HMSO.

David, R. (1966). Einführung in die großen Rechtssysteme der Gegenwart. Munich: Beck.

Denhardt, K. (1991). Ethics and fuzzy worlds. Australian Journal of Public Administration 50: 274-278.

Derlien, H. (1992). Der Rechnungshof zwischen Finanzkontrolle und Programmevaluation. in H. Hartwich \& G. Wewer (eds.), Regieren in der Bundesrepublik IV. Opladen: Leske \& Budrich, pp. 81-94.

Derlien, H. (1994). Karrieren, Tätigkeitsprofil und Rollenverständnis der Spitzenbeamten des Bundes - Konstanz und Wandel. Verwaltung und Fortbildung 22: 256-274. 
Derlien, H. \& Heinemann, S. (1998). The German public service - Structure and statistics. Bamberg: Bamberger Verwaltungswissenschaftliche Beiträge 14.

DiMaggio, P.J. \& Powell, W.W. (1991). Introduction. in W.W. Powell \& P.J. DiMaggio (eds.), The new institutionalism in organizational analysis. Chicago, IL: University of Chicago Press, pp. 1-38.

Doig, A. (1998). 'Cash for Questions': Parliament's response to the offence that dare not speak its name. Parliamentary Affairs 51:37-50.

Doig, A. (2001). Sleaze: Picking up the threads or 'back to basics' scandals? Parliamentary Affairs 54: 360-375.

Downs, A. (1957). An economic theory of democracy. New York: Harper \& Row.

Ebermayer, L. \& Jagusch, H. (1988). StGB - Leipziger Kommentar Bd. 7. Berlin: De Gruyter.

Fiorina, M.P. (1981). Retrospective voting in American national elections. New Haven, CT/London: Yale University Press.

Fry, G.K. (1985). The changing civil service. London: George Allen \& Unwin.

Funk, A. (1986). Polizei und Rechtsstaat. Frankfurt-am-Main: Campus.

Gilman, S.C. (1996). The management of ethics and conduct in the public service: The United States federal government. in OECD (ed.), Ethics in the public service: Current issues and practice. http://www.oecd.org/puma/ethics/pubs/ethicsus.htm

Gilman, S.C. (2000). An idea whose time has come: The international experience of the US Office of Government Ethics in developing anticorruption systems. Public Integrity 2: $135-155$.

Goldsmith, M.J. \& Page, E.C. (1997). Farewell to the British state? in J. Lane (ed.), Public sector reform. London: Sage, pp. 147-167.

Goldstein, J. (1988). Ideas, institutions and American trade policy. International Organization 42: 179-217.

Haffke, B. (1995). Politik und Korruption. Strafrechtliche Notizen zu den jüngsten Bestechungsskandalen. in G. Tondorf (ed.), Staatsdienst und Ethik. Baden-Baden: Nomos, pp. 11-40.

Hall, P.A. \& Taylor, R.C.R. (1996). Political science and the three new institutionalisms. Political Studies 46: 936-957.

Hart, H. (1994). The concept of law. Oxford: Oxford University Press.

Heclo, H. \& Wildavsky, A. (1974). The private government of public money. London: Macmillan.

Heiner, R.A. (1990). Rule-governed behavior in evolution and human society. Constitutional Political Economy 1: 19-46.

Heywood, P. \& Wright, V. (1997). Executives, bureaucracies and decision-making. in M. Rhodes, P. Heywood \& V. Wright (eds.), Developments in West European politics. New York: St Martin's Press, pp. 75-94.

Hodess, R., Banfield, J. \& Wolfe, T. (eds.) (2001). Global corruption report 2001. Berlin: Transparency International.

Hood, C. et al. (1999). Regulation inside government. Oxford: Oxford University Press.

Hunt, M. (2000). Parliament and ethical behaviour. in R.A. Chapman (ed.), Ethics in public service for the new millennium. Aldershot: Ashgate, pp. 23-34.

Immergut, E.M. (1997). The normative roots of the new institutionalism: Historicalinstitutionalism and comparative policy studies. in A. Benz \& W. Seibel (eds.), Theorieentwicklung in der Politikwissenschaft - eine Zwischenbilanz. Baden-Baden: Nomos, pp. 325-355. 
Kernaghan, K. \& Dwivedi, O. (1983). Public service ethics: Issues and ideas. in K. Kernaghan \& O. Dwivedi (eds.), Ethics in the public service: Comparative perspectives. Brussels: International Institute of Administrative Sciences, pp. 1-11.

Landfried, C. (1994). Parteifinanzen und politische Macht. Baden-Baden: Nomos.

Lawton, A. \& Rose, A. (1994). Organisation and management in the public sector. London: Pitman.

Leigh, D. \& Vulliamy, E. (1996). Sleaze: The corruption of parliament. London: Fourth Estate.

Leyendecker, H., Prantl, H. \& Stiller, M. (2000). Helmut Kohl, die Macht und das Geld. Göttingen: Steidl.

Lübbe-Wolff, G. (1998). Artikel 33. in H. Dreier (ed.), Grundgesetz Kommentar. Tübingen: Mohr, pp. 706-726.

Luhmann, N. (1994). Funktionen und Folgen formaler Organisation. Berlin: Duncker \& Humblot.

Maurer, H. (1999a). Staatsrecht. Munich: C.H. Beck.

Maurer, P. (1999b). Personalpolitik nach dem Regierungswechsel. in H. Derlien \& N. Strohm (eds.), Regierung und Verwaltung im Spiegel der Medien. Unpublished working paper, pp. 41-54.

Mayntz, R. \& Derlien, H. (1989). Party patronage and politicization of the West German administrative elite 1970-1987: Toward Hybridization? Governance 2: 384-404.

OECD (1996). Ethics in the public service. Paris: OECD.

OECD (2000). Trust in government. Paris: OECD.

Oliver, D. (1995). The Nolan Committee. in F.F. Ridley \& A. Doig (eds.), Sleaze: Politicians, private interests and public reaction. Oxford: Oxford University Press, pp. 42-53.

Oliver, D. (1997). Regulating the conduct of MPs: The British experience of combating corruption. Political Studies 45: 539-558.

Patzelt, W.J. (1999). Parlamentarische Rekrutierung und Sozialisation. Normative Erwägungen, empirische Befunde und praktische Empfehlungen. Zeitschrift für Politik 16: 243-282.

Philp, M. (2000). Corruption, control and convergence: The limits of globalization. Unpublished working paper.

Punnett, R.M. (1994). British government and politics. Aldershot: Dartmouth.

Richards, D. \& Smith, M.J. (2000). The public service ethos and the role of the British civil service. West European Politics 23: 45-66.

Roll, H. (1989). Verhaltensregeln. in H. Schneider \& W. Zeh (eds.), Parlamentsrecht und Parlamentspraxis in der Bundesrepublik Deutschland. Berlin: de Gruyter, pp. 607-617.

Rousseau, J. (1988). Social contract. (trans. G.D.H. Cole) Amherst, NY: Prometheus Books.

Rudolphi, H. et al. (n.d.). Systematischer Kommentar zum Strafgesetzbuch. Neuwied: Luchterhand.

Simon, H. (1955). A behavioral model of rational choice. Quarterly Journal of Economics 69: 99-118.

Sub-Committee of the First Division Association (1972). Professional standards in the public service. Public Administration 50: 167-182.

Thelen, K. \& Steinmo, S. (1992). Historical institutionalism in comparative politics. in S. Steinmo, K. Thelen \& F. Longstreth (eds.), Structuring politics: Historical institutionalism in comparative politics. Cambridge/New York: Cambridge University Press, pp. $1-32$.

Thompson, D.F. (1993). Mediated corruption: The case of the Keating Five. American Political Science Review 87: 369-381. 
Voigt, R. (1998). Von der Romanisierung zur Globalisierung? in R. Voigt (ed.), Evolution des Rechts. Baden-Baden: Nomos, pp. 119-154.

Wagner, F. (1988). Beamtenrecht. Heidelberg: R. von Decker.

Weir, M. (1989). Ideas and politics. in P.A. Hall (ed.), Economic ideas: Keynesianism across nations. Princeton, NJ: Princeton University Press, pp. 53-86.

Whetnall,A. (1996). The management of ethics and conduct in the public service: The United Kingdom. in OECD (ed.), Ethics in the public service: Current issues and practice. http://www.oecd.org/puma/ethics/pubs/ethicsgb.htm.

Woodhouse, D. (1998). The Parliamentary Commissioner for Standards: Lessons from the 'Cash for Questions' inquiry. Parliamentary Affairs 51: 51-61.

Wunder, B. (1974). Die Entstehung des modernen Staates und des Berufsbeamtentums in Deutschland im frühen 19. Jahrhundert. Leviathan 2: 459-478. 